\title{
INTERVENSI CYTOADHERENCE SEBAGAI PELUANG UNTUK PENCEGAHAN DAN TERAPI MALARIA BERAT
}

\section{THE INTERVENTION OF CYTOADHERENCE, A CHANCE IN PREVENTION AND TREATMENT OF SEVERE MALARIA}

\author{
Dorta Simamora, * Sutiman B. Sumitro, ${ }^{* *}$ Loeki Enggar Fitri ${ }^{* * *}$ \\ * Laboratorium Biologi, Fakultas MIPA Universitas Satya Wyata Mandala (USWIM) Nabire, Papua \\ ** Laboratorium Biologi Fakultas MIPA Universitas Brawijaya \\ *** Laboratorium Parasitologi Fakultas Kedokteran Universitas Brawijaya
}

\begin{abstract}
In malarial infection, erythrocytes infected wih Plasmodium falciparum bind to endothelial vascular (endothelial cytoadherence). This binding is implicated in the forming of sequestre and rosette that affects the vascular circulation, and thus injures the capillary wall. This mechanism is important in pathogenesis of malarial due to dysfunction of several organs. There are several receptors of cytoadherence in human e.g Thrombospondine (TSP), CD-36, ICAM-1, and ELAM-1 as well as specific ligands of the parasite e.g Plasmodium falciparum Erythrocyte Membrane Protein-1 (PfEMP1), $220 \mathrm{kDa}$ protein of Pf60, Pf332, sequestrin, Pfaldhesin and STEVOR. PfEMP-1 has been revealed as a molecule that is responsible for pathogenesis of severe malaria. This protein can pass parasitophorous vacoular membrane (PVM) of the parasite by attaching its molecule to carry Protein Export Elemen (PEXEL) and than go to the surface of erythrocytes in combination with specific helper protein in maeurer cleft. The intervention on cytoadherence process through blocking of specific ligand directly or blocking the translocation of this ligand to the surface of erythrocytes might be important in regulating the outcome of malarial infection.

Key words : Cytoadherence, severe malaria, intervention, adhesion molecule.
\end{abstract}

\section{PENDAHULUAN}

Siklus eritrositik dari Plasmodium falciparum yang menyerang manusia memiliki mekanisme yang berbeda bila dibandingkan dengan spesies Plasmodium lain. Trophozoite dan schizont dewasa akan hilang dari sirkulasi perifer akibat adanya adhesi eritrosit yang terinfeksi pada sel endotel kapiler pembuluh organ dalam. Adhesi eritrosit menghasilkan maturasi yang lebih baik dalam lingkungan mikroaerofilik venous serta akan membuat parasit ini terhindar dari proses pembersihan dari limpa. Dalam tekanan gas yang rendah parasit akan lebih cepat berdiferensiasi dan eritrosit bentuk aseksual (trophozoite dan schizont) juga akan lebih cepat menjadi matur (1).

Protein adhesi yang terletak pada permukaan eritrosit yang terinfeksi disebut knob. Knob ini akan memudahkan terjadinya adhesi pada sel endotel dan eritrosit lainnya.. Adhesi pada endotel atau cytoadherence, berperan penting dalam patogenesis penyakit, karena dapat menyebabkan oklusi pada pembuluh darah kecil serta dapat menyebabkan gagal fungsi pada beberapa organ. Protein membran eritrosit 1 dari $P$. falciparum (PfEMP-1)

Jurnal Kedokteran Brawijaya, Vol. XXII, No.2, Agustus 2006 Korespondensi: Loeki Enggar Fitri; Laboratorium Parasitologi Fakultas Kedokteran Universitas Brawijaya, jl. Veteran Malang 65145. Telp: 569117,e-mail: Lukief@brawijaya.ac.id merupakan ligand adhesif utama dari eritrosit yang terinfeksi (1).

Cytoadherence dapat mengakibatkan kerusakan pada dinding pembuluh darah kapiler serta dapat menghambat aliran darah ke pembuluh darah kapiler karena terbentuknya sequester dan rosette. Proses tersebut menyebabkan terjadinya edema dan hipoksia karena adanya kebocoran kapiler dan berkurangnya aliran darah. (2).

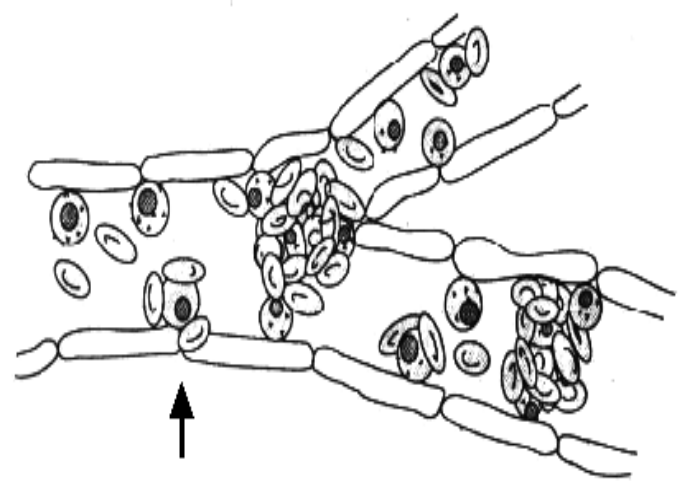

Gambar 1. Eritrosit dalam Keadaan Terinfeksi Parasit P. falciparum (1). 
Knob yang berisi protein PfEMP-1 dari parasit ini sangat esensial untuk perlekatan yang kuat dengan sel endotel sesuai konsentrasi protein ligand di dalamnya. Pada kondisi static binding assay, eritrosit terinfeksi p.falciparum, yang tidak mengandung knob, juga dapat mengadakan perlekatan dengan sel endotel (3).

Cytoadherence terjadi akibat interaksi molekuler dari ligand Plasmodium falciparum Erythrocyte Membrane Protein-1 (PfEMP-1) dengan reseptor yang terdapat pada membran sel endotel. Reseptor tersebut adalah Cluster of Differentiation-36 (CD-36), Intercellular Adhesion Molecule1 (ICAM-1), Vascular Cell Adhesion Molecule-1 (VCAM-1), CD-31 atau Platelet Endothelial Cell Adhesion Molecule (PECAM)) trombospodin, dan E-Selektin. Berbagai reseptor tersebut tidak terdistribusi secara seragam pada semua sel endotel. Beberapa dari reseptor ini ekspresinya dirangsang oleh sitokin pro inflamasi seperti Interleukin-1 (IL-1), Tumour Necrosis Factor- $\alpha$ (TNF- $\alpha$ ) dan Interferon- $\gamma$ (IFN- $\gamma$ ) dan juga Lipopolysaccaride (LPS)(4).

Pencegahan malaria berat dikaitkan dengan proses cytoadherence. Mampukah intervensi terhadap proses cytoadherence tersebut mencegah terjadinya kerusakan pada sel endotel?

\section{Mekanisme Molekuler Cytoadherence}

Beberapa penjelasan menerangkan, bahwa ada hubungan antara biologi siklus intraeritrositik aseksual dengan patogenesis penyakit. Merozoite hanya beberapa saat saja berada dalam milieu ekstraselular sebelum menempel pada dan masuk ke dalam eritrosit. Jika tidak demikian maka merozoite akan mati. Ketahanan dan reproduksi merozoite dalam eritrosit tergantung pada konstituen intraselluler dari membran plasma eritrosit dan sitoplasma, karena akan mempengaruhi pengangkutan pada membran sel melalui vakuola parasitoforus dan dari parasit itu sendiri. Infeksi karena parasit dapat mengubah struktur dan fungsi eritrosit. Selanjutnya antigen dari parasit akan muncul pada permukaan eritrosit terinfeksi. Eritrosit yang terinfeksi $P$. falciparum ini akan memicu terjadinya pengikatan pada sel endotel kapiler dan venular (Cytoadherence), sehingga menghasilkan sequestration pada postkapilar venule organ dalam (1).

\section{Reseptor Inang yang Berimplikasi dalam Cytoadherence}

Beberapa molekul dikatakan sebagai reseptor eritrosit terinfeksi malaria pada sel endotel didasarkan pada kemampuannya untuk mendukung adhesi pada eritrosit yang terinfeksi selama assay in vitro (Tabel 1 \& Gambar 2).

Thrombospondine (TSP) merupakan reseptor dari cytoadherence terkait dengan protein pada membran eritrosit terinfeksi $P$. falciparum yang disebut dengan PfEMP-1. Belum diketahui domain PfEMP-1 mana yang bertanggung jawab pada proses adhesi dengan $\operatorname{TSP}(5,6)$.
CD36 merupakan reseptor kedua dari cytoadherence terdapat pada monocyte, sel endotel, platelet dan erythroblast $(7,8,9)$. Semua domain Cysteine Rich Interdomain Region-1 $\alpha$ (CIDR1 $\alpha$ ) dari PfEMP-1 terikat dengan klon 3D7 dari CD36 (10). Sub fragmen Cysteine Rich Interdomain Region (CIDR) rekombinan dari 179 residu yang terikat dengan $\mathrm{CD} 36$, dapat menghambat adhesi pada eritrosit terinfeksi $P$. falciparum (11).

Molekul adhesi pada sel endotel ICAM-1 bertindak sebagai reseptor pada eritrosit terinfeksi $P$. falciparum (12). ICAM-1 terikat pada domain PfEMP-1 yang pertama dan kedua (13). Domain DBL2 $\beta$ dari PfEMP-1, bersama dengan domain C2, berikatan dengan ICAM-1 (14). ICAM-1 berperan penting terhadap terjadinya malaria serebral $(12$, 15).

Endothelial Leucocyte Adhesion Molecule-1 (ELAM1) atau E-Selektin dan VCAM-1 merupakan reseptor potensial pada sequestration eritrosit terinfeksi (16). Dalam keadaan normal molekul tersebut tidak terekspresi pada sel endotel tetapi akan aktif bila dirangsang dengan IL-1 dan TNF- $\alpha$. Belum jelas diketahui protein ligand parasit mana yang berperan dalam proses adhesi dengan kedua reseptor diatas. Hubungan antara sindrom klinis dan adhesi terhadap reseptor ini tidak ditemukan dalam isolat klinis. Interaksi antara eritrosit terinfeksi P.falcifarum dengan P-selectin dapat terjadi melalui domain lektin yang bersifat $\mathrm{Ca}^{2+}$ dependent. Belum ada studi tentang adhesi dan penyakit klinis yang dipublikasikan khususnya yang terkait dengan reseptor ini. $(17,18)$.

Reseptor yang juga penting untuk adhesi eritrosit terinfeksi $P$. falciparum juga terdapat pada plasenta adalah Chondroitin-4-sulfat (CSA) dan glikosaminoglikan $(19,20)$. Kedua molekul tersebut menggunakan domain PfEMP-1 yaitu DBL3 (21) CIDR (22) sebagai ligand. Adhesi ini sangat dependen dengan sulfasi 4-0 dari rantai sakarida (23). Hyaluronic Acid ( $\mathrm{HA})$ merupakan reseptor lain yang penting pada sequestration di plasenta (24). Biasanya eritrosit terinfeksi memiliki spesifisitas ganda karena dapat berikatan dengan dua reseptor.

Heparin sulfate (HS) disebut juga sebagai reseptor inang, karena dapat memicu cytoadherence pada sel endotel dan aorta oleh PfEMP-1 (25). Temuan terbaru memperlihatkan bahwa ikatan ini dapat dibentuk oleh domain Duffy Binding Like-1a (DBL1 $\alpha)$ (26).

Molekul adhesi sel endothelial-platelet 1 (PECAM-1 atau CD31) mempunyai keterlibatan dengan cytoadherence pada isolat field yang menggunakan PfEMP-1 sebagai ligand (27). Analisis polimorfisme PECAM-1 pada pasien malaria menunjukkan bahwa frekuensi satu genotipe sangat beresiko menjadi malaria serebral (28). Reseptor sel endotel lainnya pada skala kecil selama infeksi seperti alfa (v) beta3 atau integrin terlibat dengan beberapa proses adherensi patologis dan fisiologis. Kemampuan eritrosit 
terinfeksi melakukan adhesi dengan alpa (v) beta3 pada sel endotel adalah 7-270 kali lebih besar bila dibandingkan dengan eritrosit yang tidak terinfeksi (29).

Data tersebut di atas menunjukkan bahwa isolat lapangan penyebab cytoadherence akan berikatan dengan reseptor inang yang berbeda-beda. Meskipun demikian, studi di lapangan menunjukkan bahwa spesifitas reseptor inang dari hampir semua parasit dari pasien terinfeksi adalah CD36 dan TSP (30). CD36 menjadi reseptor kuantitatif yang paling penting diikuti oleh ICAM-1 karena menyebabkan $80 \%$ isolatnya mengalami adherensi. Sebaliknya, adhesi minimal atau tanpa adhesi dengan Eselectin, VCAM-1, atau CSA terdapat pada sebagian besar isolat (31). Hasil yang sama juga dapat diperoleh dari isolat Brazil dengan menggunakan assay cytoadherence (32). ICAM-1 juga berperan penting sebagai penyebab malaria serebral, beberapa upaya dari peneliti gagal menghubungkan ikatan tersebut dengan reseptor tertentu pada sindrom spesifik sebagai penyebab malaria serebral $(33,34)$.

\section{Ligand Parasit Yang Berimplikasi Dalam Cytoadherence}

Selain PfEMP-1, protein parasit lain yang terdapat pada permukaan eritrosit terinfeksi juga berpartisipasi sebagai penyebab terjadinya cytoadherence (Tabel 1). Cytoadherence Linked asexual gene9 (CLAG9) merupakan famili multi gen, mengandung 9 gen, terdapat pada beberapa kromosom (35). Clag9 diperkirakan sebesar $7 \mathrm{~kb}$, dan diperkirakan berisi 9 exon. CLAG9 terletak pada kromosom 9, terdiri dari parasit matur, kemudian ditranslasikan menjadi protein $220 \mathrm{kDa}$. Lokalisasi seluler dari protein tetap perlu ditentukan melalui prediksi struktural. Terdapat empat protein yang muncul pada domain transmembran, dari eritrosit terinfeksi. Melalui transfeksi dengan menggunakan teknologi antisense, menunjukkan bahwa protein $220 \mathrm{kDa}$ dan CLAG merupakan ligand dari CD36 (36).

Pf60 pertama sekali dikatakan sebagai famili multigen (37) mempunyai sekitar 140 gen. Domain terminal$\mathrm{N}$ tidak homolog dengan berbagai protein yang ditetapkan sebelumnya. Sebaliknya, terminal-C exon 7 memiliki homolog yang tinggi dengan exon II dari gen var serta berhubungan dengan cytoadherence (38).

Pf332 adalah protein megadalton yang secara spesifik diekspresikan pada parasit tahap darah dewasa yang aseksual, kemudian ditranslokasikan dari parasit ke permukaan eritrosit melalui polimorfisme tertentu (39). Antibodi monoklonal Pf332 secara in vitro menghambat cytoadherence (40), antibodi poliklonal Pf332 menghambat pertumbuhan parasit tetapi bukan cytoadherence (41), namun perannya secara langsung pada cytoadherence masih terbatas.

Sekuestrin adalah sebuah protein $270 \mathrm{kDa}$ yang ditentukan dengan penggunaan antibodi dengan meniru adhesi CD36 (42).
Pfalhesin merupakan protein band 3 yang dimodifikasi oleh parasit. CD36 dan TSP dikatakan sebagai ligand cytoadherence dengan protein ini. Ikatan eritrosit terinfeksi pada TSP dapat terjadi oleh domain T3 yang dipicu oleh sekuensi peptida HPLQKTY dari protein band 3 (43).

Subtelomeric Variant Open Reading Frame (STEVOR) dikatakan sebagai 7 h8 (44), terlihat unik terhadap $P$. falciparum. Gen tersebut termasuk dalam famili multigen dengan 30-40 anggota yang berada pada area subtelomerik pada semua kromosom (45). Gen stevor mempunyai 2 exon. Exon 1 cenderung pendek yang menginisiasi kodon domain transmembran. Exon kedua ( $1 \mathrm{~kb}$ ) tersusun dari protein $30 \mathrm{kDa}$ yang terdiri atas dua segmen transmembran (46). Transkripsi beberapa gen stevor dibatasi apabila invasinya sudah mencapai 22-32 jam. Protein STEVOR diangkut melalui celah Maurer kemudian ditempatkan di sub membran eritrosit. Selain itu, sequestration gametosit yang disebabkan adanya protein PfEMP-1 tidak ditemukan. STEVOR dapat mengaktifkan cytoadherence (47).

\section{Translokasi protein pada eritrosit yang terinfeksi plasmodium}

Translokasi protein parasit ke permukaan eritrosit dapat dilakukan dalam dua tahap: (1) translokasi antigen parasit yaitu PfEMP-1 dan Knob Associated Histidine Rich Protein (KAHRP) melalui Carry Protein Export Element (PEXEL) sehingga memungkinkannya melewati Parasitophorous Vacuolar Membrane (PVM), kemudian (2) bergabung dengan translokasi spesifik atau helper protein di Maurer cleft. Helper protein in i akan membawa kedua protein tersebut, menuju membran eritrosit dan membentuk knob. Pada knob, KAHRP terikat dengan Acidic Terminal Segment (ATS) di PfEMP-1 sedangkan PfEMP-1 sendiri terhubung dengan actin spectrin 4.1 pada sitoskeleton eritrosit (49).

Mekanisme transfer protein PfEMP-1 melalui Maurer clefts menuju knob di membran eritrosit belum begitu jelas. Papakrivos \& Wellems (2005) melaporkan jalur perjalanan PfEMP-1 menuju membran eritrosit dengan menggunakan Green Fluorescent Protein (GFP) chimeras, pola penyortiran dan transport protein melalui Maurer clefts ini sangat penting. Pada sitoplasma eritrosit, beberapa molekul PfEMP-1 dari parasit yang matang melekat lalu menyatu dengan helper protein sehingga menyebabkan penebalan pada mantel Maurer clefts, namun ATS di sitoplasma eritrosit menjadi tidak terlindungi (49). Saat terjadinya penggabungan protein tersebut, protein akan menonjol keluar pada permukaan eritrosit dan membentuk knob. Knob selanjutnya akan bergabung dengan KAHRP melalui pemisahan protein-protein kompleks yang terdapat pada sitoplasma (Gambar 3) (49). 


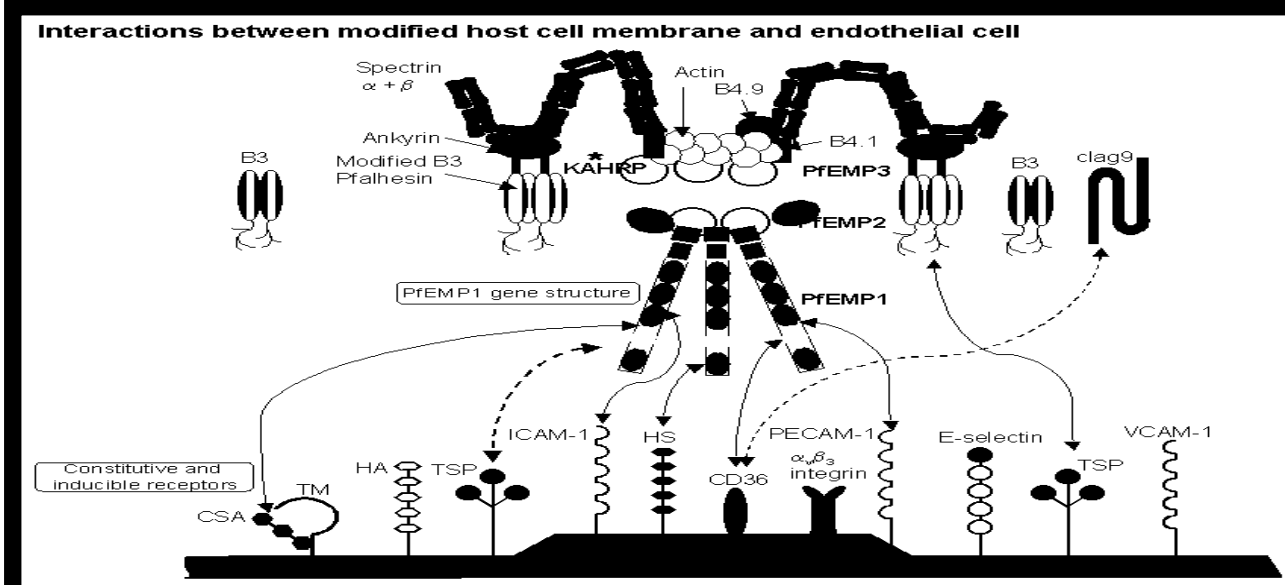

Compiled in collaboration with Erian Cooke and Leann Tiller

\section{Gambar 2.Interaksi Molekul yang Terlibat Dalam Proses Cytoadherence pada Eritrosit Terinfeksi dengan Sel Endotel (48)}

$\begin{array}{lllll}\text { Keterangan: } & \text { 5. } & \text { HS } & : \text { Heparan Sulphate } \\ \text { CSA } & \text { : Chondroitin-4-Sulfat } & 6 . & \text { PECAM-1 } & : \text { Platelet Endothelial Cell Adhesion Molecule-1 } \\ \text { HA } & : \text { Hyaluronic Acid } & \text { 7. } & \text { VCAM-1 } & : \text { Vascular Cell Adhesion Molecule-1 } \\ \text { TSP } & : \text { Trombospodin } & \text { 8. } & \text { KAHRP } & : \text { Knob Associated Histidine Rich Protein } \\ \text { CD36 } & : \text { Cluster of Differentiation-36 } & \text { 9. } & \text { PFEMP } & \text { : Plasmodium Falciparum Erythrocyte Membrane } \\ & & & & \text { Protein }\end{array}$

Tabel 1. Reseptor Inang dan Ligand Parasit yang Berperan dalam cytoadherence (1)

\begin{tabular}{|c|c|c|c|}
\hline $\begin{array}{l}\text { Host Receptors } \\
\text { (synonymous) }\end{array}$ & $\begin{array}{l}\text { Parasite Ligands } \\
\text { (domain) }\end{array}$ & $\begin{array}{l}\text { Relevant Remarks } \\
\text { of each interaction }\end{array}$ & References \\
\hline TSP & PfEMP-1 & Low affinity of binding in flow conditions & Robets et al. 1985, Baruch et al. 1996 \\
\hline$C D$ & PfEMP-1 (CDR 1 $\alpha)$ & Most common binding phenotype & $\begin{array}{l}\text { Oquendo et al. 1989, Barnwell et al. 1989, } \\
\text { Barunch et al. 1995, 1996, } 1997\end{array}$ \\
\hline ICAM-1 (CD 54) & PfEMP1 (DBL2 $\beta C 2)$ & $\begin{array}{c}\text { Receptor member of the immunoglobulin } \\
\text { superfamily }\end{array}$ & $\begin{array}{c}\text { Berendt et al. 1989, 1992, Baruch et al. } \\
\text { 1996, Smith et al. 2000a }\end{array}$ \\
\hline $\begin{array}{l}\text { ICAM-1 (CD } \\
\text { 62E)(E-selektin) }\end{array}$ & $?$ & Uncommon target of Binding & (Ockenhouse et al. 1992) \\
\hline VCAM-1 (CD106) & $?$ & $\begin{array}{l}\text { Receptor member of the immunoglobulin } \\
\text { superfamily/Uncommon target of binding }\end{array}$ & $\begin{array}{l}\text { Ockenhouse et al. 1992, Newbold et al. } \\
\text { 1997a,b }\end{array}$ \\
\hline P-selectin & PfEMP-1 & Binding is $\mathrm{Ca} 2+$ dependent; ligand is questioned & Ho et al. 1998 \\
\hline CSA & $\begin{array}{l}\text { PfEMP1 (DBL3 } \gamma) \\
\quad(\text { CIDR1) }\end{array}$ & Binding important im malaria (during pregnancy) & $\begin{array}{l}\text { Rogerson at al. 1995, Fried and Duffy } \\
\text { 1996, Buffet et al. 1999, Reeder et al. } 1999\end{array}$ \\
\hline $\mathrm{HA}$ & PfEMP1 & Receptor that mediates adhesion to placenta & Beeson et al. 2000 \\
\hline HS & PfEMP1 (DBL1 $\alpha)$ & Receptor presents in endothelial cells and aorta & Barragan et al. 2000b, Vogt et al. 2003 \\
\hline PECAM-1 (CD31) & $\begin{array}{l}\text { PfEMP1 (DBL2 } \delta) \\
\text { (CIDR1) }\end{array}$ & Uncommon target of Binding & Treutiger et al. 1997, Chen et al. 2000 \\
\hline CD 36 & Sequestrin & Binding id Questioned & Ockenhouse et al. 1991 \\
\hline CD 36/TSP & Pfalhesin & Ligand are fragments of a modified Band 3 & Crandall et al. 1993, 1994, Eda et al. 1999 \\
\hline CD 36 & CLAG & Knockout of clag9 gene inhibits this adhesion & Holt et al. 1999, Trenholme et al.2000 \\
\hline$?$ & Pf60 & $\begin{array}{l}\text { C-terminal exon } 7 \text { of pf60 genes present high } \\
\text { homology with exon II of var genes }\end{array}$ & $\begin{array}{l}\text { Carcy et al. 1994, Bonnefoy et al. 1997, } \\
\text { Bischoff et al. } 2000\end{array}$ \\
\hline$?$ & Pf332 & Obscure participation in cytoadherence & $\begin{array}{c}\text { Mattei and Scherf 1992, lqbal et al. 1993, } \\
\text { Ahlborg et al. } 1995\end{array}$ \\
\hline
\end{tabular}




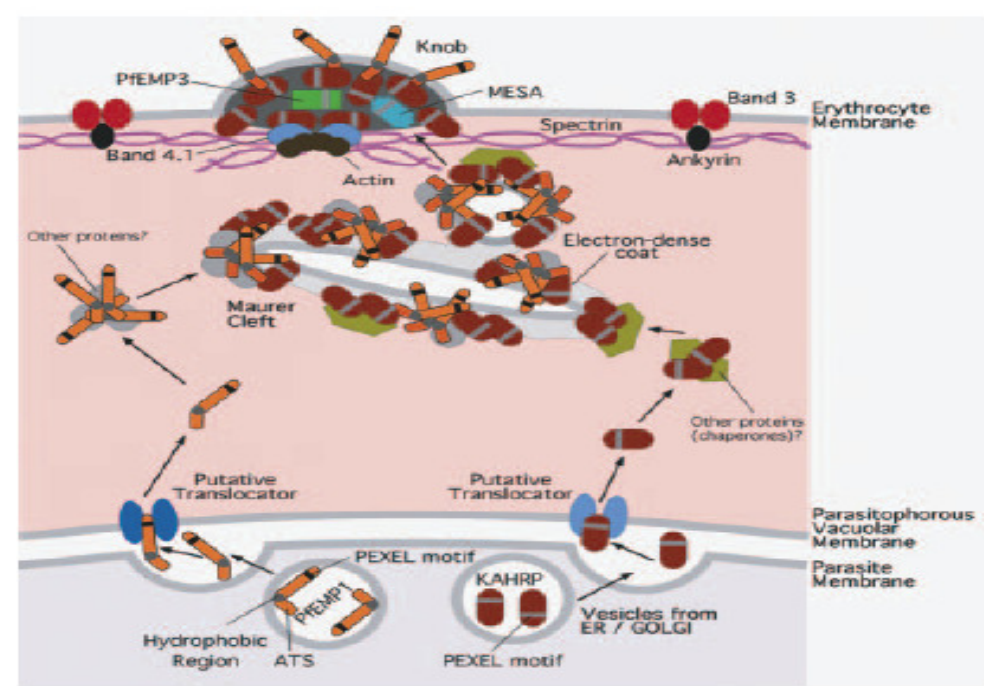

Gambar 3. Translokasi Protein pada Eritrosit yang Terinfeksi Plasmodium (50).

\section{Mekanisme Molekuler Interaksi Cytoadherence}

Pada kondisi flow binding assay, eritrosit terinfeksi P.falciparum mengadakan interaksi dengan sel endotel melalui beberapa tahap yaitu: tethering, rolling, dan firm adhesion.
CD-36, ICAM-1, P-Selektin dan VCAM-1 berfungsi untuk menginisiasi terjadinya tethering supaya dapat rolling. Kekuatan dan kecepatan interaksi dari rolling terletak pada masing-masing dari molekul reseptor, kemudian diikuti adhesi dibawah kontrol dari CD-36 (3).

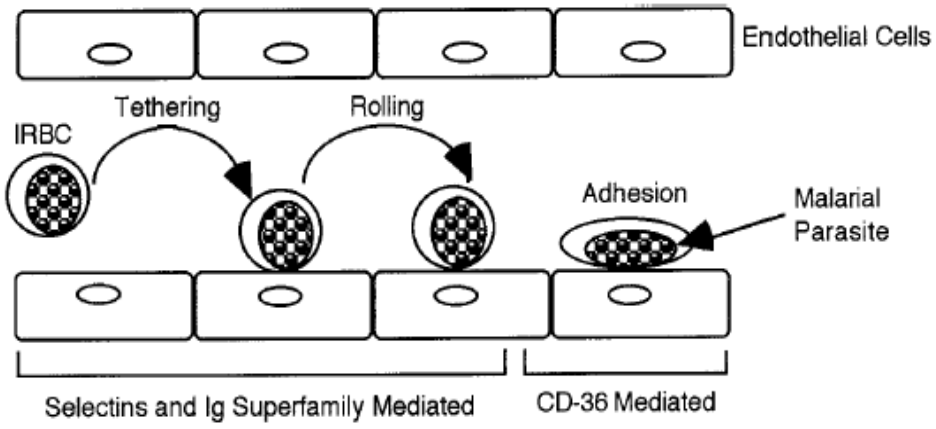

Gambar 4. Mekanisme Molekuler pada Interaksi Cytoadherence (3)

Sekali eritrosit terinfeksi parasit mengadakan adhesi pada sel endotel, maka eritrosit tersebut tidak akan terlepas lagi dan tidak akan bersirkulasi lagi, kecuali jika secara in vivo terus terjadi perkembangan stadium sehingga schizonts menjadi mature, kemudian pecah dengan meninggalkan eritrosit kosong yang tetap melekat pada sel endotel (a cytoadherence red cells ghost). Bentuk merozoite akan segera kembali ke sirkulasi dan menginfeksi eritrosit lain yang baru, mengingat aliran darah pada awalnya tidak berhenti.

Hal inilah yang menjelaskan mengapa bentuk schizont tidak banyak ditemukan di sirkulasi perifer tetapi bentuk trophozoites dan bentuk cincin masih dapat ditemukan di perifer (4).

Fitri (2004) melaporkan, peningkatan ekspresi ekspresi ICAM-1 berkaitan dengan peningkatan kemampuan cytoadherence eritrosit terinfeksi $P$. falciparum isolat Malang pada sel endotel (HUVEC's) (51). Melalui penelitian in vitro juga dibuktikan bahwa cytoadherence dapat menginduksi ekspresi Inducible Nitric Synthase (iNOS) Pada sel endotel (HUVEC's) serta dapat menginduksi produksi Reaktive Oxygen Intermediate (ROI) oleh sel endotel (HUVEC's). Penambahan TNF-a juga dapat meningkatkan produksi $R O I$ oleh sel endotel (HUVEC's) in vitro. Terjadi tanda-tanda apoptosis awal pada beberapa sel endotel yang dilekati oleh $P$. falciparum yang mengekspresikan iNOS (51).

\section{Intervensi terhadap Cytoadherence}

Terhambatnya aliran darah arteri pada jaringan mengakibatkan organ lebih sensitif terhadap gangguan, misalnya otak. Otak sangat sensitif terhadap hipoksia.. Studi patogenesis terhadap stroke menunjukkan bahwa infark serebral, serta hilangnya fungsi jangka panjang, 
apabila tekanan intrakranial berkisar 15 sampai $20 \mathrm{~mm} \mathrm{Hg}$ atau lebih rendah selama periode 20 sampai 30 menit. Hal Ini berbeda dengan koma oligemik sederhana pada infeksi malaria yang secara cepat akan mengembalikan fungsi neurologisnya secara penuh Sebagian besar pasien yang sembuh dari malaria serebral tidak mengalami defisit neurologi residual (52).

Sebagian besar komplikasi yang mengancam kehidupan penderita malaria falciparum adalah hipoksia pada jaringan sirkulasi mikro diawali oleh cytoadherence sehingga menyebabkan hemolisis ekstensif. Diduga ada toksin parasit atau produk terlarut dari sel imun (makrofag) seperti TNF atau radikal oksigen toksik, namun belum ada bukti yang mendukung untuk meyakinkan hal ini. Di lain pihak, belum ada informasi tentang bagaimana individu mempunyai kekebalan terhadap penyakit sehingga dapat dilindungi dari beberapa komplikasi klinis karena infeksi, tanpa memperhatikan efek langsung dari anti parasit. Diduga toleransi tersebut merupakan modifikasi patologi mikrovaskuler atau sebuah respon anti toksik terhadap produk parasit atau sel imun. Pengamatan dengan menggunakan pendekatan tersebut menjadi terobosan baru yang akan bermanfaat pada terapi baru (52)

Intervensi terhadap cytoadherence merupakan usaha untuk membuat gangguan pada perlekatan eritrosit penderita malaria falciparum dengan sel endotel, sehingga terhambatnya aliran darah arteri pada jaringan dapat dicegah. Intervensi dapat dilakukan dengan dua cara (1) blocking ligand dan parasit dan (2) blocking translokasi protein parasit ke permukaan eritrosit. Berdasarkan studi in vitro dan in vivo malaria pada simian (sejenis monyet), menunjukkan adanya antibodi yang berikatan dengan antigen pada eritrosit yang terinfeksi oleh $P$. falciparum akan mengintervensi cytoadherence pada sel endotel. Intervensi oleh antibodi pada ligand parasit dapat menghilangkan sequestration.

Beberapa penyelidik mencoba mengidentifikasi antigen target yang berhubungan dengan sistem pertahanan dan memperpertimbangkan ligand pada cytoadherence menjadi kandidat vaksin yang potensial. Antigen cytoadherence secara teoritis dapat digunakan sebagai target bukan hanya dari segi immunoprofilaksis tetapi juga dari segi imunoterapi, karena pengadaan antibodi secara cepat dapat memblok cytoadherence sehingga dapat melemahkan beberapa patologi mikrovaskular penyebab komplikasi melalui blocking sequestration parasit (52).

Kesulitan dalam intervensi cytoadherence adalah karena antigen cytoadherence yang sangat beragam. Sangat sulit untuk dibayangkan, bagaimana proses pemblokan pada cytoadherence melalui proses biologi apabila tidak ada ligand yang sama pada turunan parasit selanjutnya, oleh karena domain variabel antigen cytoadherence yang sangat kompleks (1).

Beberapa studi telah menunjukkan bahwa sekuensi protein PfEMP-1 berhubungan dengan malaria berat. Studi pada area hipoendemik dari Guyana Perancis yang melibatkan 19 pasien malaria berat menunjukkan bahwa, ada sekuensi var DBL $\delta$ yang diekspresikan oleh pasien ini tapi tidak pada 32 pasien dengan malaria sedang (53). Hasil yang sama diperoleh di Brazil dimana parasit dari pasien dengan malaria berat mentranskripsikan sekuensi var DBL $1 \alpha$ dengan residu 1-2 cistein yang rendah, sedangkan parasit dari pasien dengan malaria sedang mentranskripsikan sekuensi var $\mathrm{DBL} 1 \alpha$ tanpa adanya delesi. (54) Investigasi terbaru memperlihatkan bahwa turunan $P$. falciparum berkaitan dengan malaria berat dengan PfEMP-1 yang ditunjukkan oleh gen var kelompok A, yang ditranskripsikan melalui telomer (55). Data ini menunjukkan bahwa ada hubungan antara sekuensi PfEMP-1 dengan malaria berat. Meskipun demikian, studi ini masih dirumitkan dengan adanya variasi ekstensif dan transkripsi simultan dari gen var dan kesulitan teknik. Selain famili multi gen var, famili multi gen lainnya seperti rif, stevor, clag dan Pf60, cenderung terlibat dalam perihal virulensi yang muncul dalam $P$. falciparum. Fenotipe yang ditranskripsikan oleh parasit yang bersirkulasi dapat berbeda dengan fenotif yang berasal dari sequestration (56). Metodologi throughput yang tinggi dapat dilakukan untuk menemukan dan membandingkan susunan dan ekspresi gen dari virulensi genomik pada sirkulasi penderita falciparum didaerah endemik. Peristiwa tersebut seringkali disertai sindrom klinis tertentu karena malaria berat. Metode tersebut bertujuan untuk menghasilkan vaksin malaria berbasis PfEMP-1.

\section{KESIMPULAN}

1. Cytoadherence melibatkan parasit ligand yaitu: Plasmodium falciparum Erythrocyte Membrane Protein1 (PfEMP-1), protein $220 \mathrm{kDa}$ dari Pf60, Pf332, sequestrin, Pfaldhesin dan STEVOR. PfEMP-1

2. Cytoadherence, melibatkan beberapa reseptor inang, yakni Thrombospondine (TSP), CD-36, ICAM-1, ELAM1 dan parasit ligand (domain); Plasmodium falciparum Erythrocyte Membrane Protein-1 (PFEMP-1), Cytoadherence Linked asexual gene (CLAG), Subtelomeric Variant Open Reading Frame (STEVOR).

3. Intervensi terhadap cytoadherence dapat dilakukan melalui dua cara, yakni (1) blocking ligand dari parasit serta (2) blocking translokasi protein parasit ke permukaan eritrosit.

4. Berbagai penelitian yang mencoba mengintervensi terhadap cytoadherence membuka peluang dan terobosan baru terapi bagi penyembuhan terhadap penderita malaria berat. 


\section{DAFTAR KEPUSTAKAAN}

1. Kirchgatter K, \& Del-Portillo HA. Clinical and Molecular Aspects of Severe Malaria. Anais da Academia Brasileira de Ciências 2005;77(3): 455-475

2. Chen O, Heddini A, Barragan A, Fernandez V, Pearce SFA, and Wahlgren M. The Semiconserved Head Structure of Plasmodium falciparum Erythrocyte Membrane Protein 1 Mediates Binding to Multiple Independent Host Receptors. 2000;192(1): 1-9

3. Ho M, White MJ, Molecular Mechanism of Cytoadherence in Malaria. The American Physiological Society 1999; 0363(6143):C1231-C1242.

4. Silamut K, Phu NH, Whitty C, et al. Aquantitative Analysis of Microvascular Sequestration of Malaria Parasite in the Human Brain, Am.J.Pathol. 1999;155(2):395-410.

5. Roberts DD, Sherwood JA, Spitalnik SL, et al. Thrombospondin binds falciparum malaria parasitized erythrocytes and may mediate cytoadherence. Nature 1985;318: 64-66.

6. Baruch DI, Gormely JA, Ma C, Howard RJ and Pasloske BL. Plasmodium falciparum erythrocyte membrane protein 1 is a parasitized erythrocyte receptor for adherence to CD36, thrombospondin, and intercellular adhesion molecule 1. Proc Natl Acad Sci USA 1996; 93: 3497-3502.

7. Barnwell JW, Asch AS, Nachman RL, Yamaha M, Aikawa M, Ingravallo. A human 88 kD membrane glycoprotein (CD 36) functions in vitro as a receptor for a cytoadherence ligand on Plasmodium falciparum infected erythrocytes. J. Clin. Invest. 1989;84:765-772.

8. Baruch DI, Ma XC, Singh HB, Bi X, Pasloske BL and Howard RJ. Identification of a region of PfEMP-1 that mediates adherence of Plasmodium falciparum infected erythrocytes to CD36: conserved function with variant sequence. Blood 1997;90: 3766-3775.

9. Horrocks P, Pinches R, Chakravorty SJ, et al. PfEMP-1 expression is reduced on the surface of knobless Plasmodium falcifarum infected erythrocytes. J. of cell science 2005;118: 2507-2518.

10. Robinson BA, Welch TL and Smith JD. Widespread functional specialization of Plasmodium falciparum erythrocyte membrane protein 1 family members to bind CD36 analysed across a parasite genome. Mol Microbiol 2003; 47:126578.

11. Cooke BM, Nicoll CL, Baruch DI and Coppel RL. A recombinant peptide based on PfEMP-1 blocks and reverses adhesion of malaria-infected red blood cells to CD36 under flow. Mol Microbiol1998.;30: 83-90.

12. Berendt AR, Simmons DL,Tansey J, Newbold Cl and Marsh K. Intercellular adhesion molecule-1 is an endothelial cell adhesion receptor for Plasmodium falciparum. Nature 1989;341:57-59.

13. Berendt AR, Mcdowall A, Craig AG, et al. The binding site on ICAM-1 for Plasmodium falciparum infected erythrocytes overlaps, but is distict from, the LFA-1 binding site. Cell 1992;68:71-81.

14. Smith JD, Craig AG, Kriek N, et al. Identification of a Plasmodium falciparum intercellular adhesion molecule- 1 binding domain: a parasite adhesion trait implicated in cerebral malaria. Proc Natl Acad Sci USA 2000;97:1766-1771.

15. Fernandez-Reyes D, Craig AG, Kyes SA, et al. A high fequency African Coding polymorphism in the N-terminal domain of ICAM-1 presdiposing to cerebral malaria in Kenya. Hum. Mol. Genetic 1997;6:1357-1360.

16. Ockenhouse CF, Tegoshi T, Maeno Y, et al. Human vascular endothelial cell adhesion receptors for Plasmodium falciparuminfected erythrocytes: roles for endothelial leukocyte adhesion molecule 1 and vascular cell adhesion molecule 1. J Exp Med 1992;176: 1183-1189.

17. Udomsangpetch R, Taylor BJ, Looareesuwan S, White NJ, Elliott JF and Ho M. Receptor specificity of clinical Plasmodium falciparum isolates: nonadherence to cell-bound E-selectin and vascular cell adhesion molecule-1. Blood 1996;88: 2754-2760.

18. Newbold C, Warn P, Black G, et al. Receptor-specific adhesion and clinical disease in Plasmodium falciparum. AmJTrop Med Hyg 1997b;57:389-398.

19. Rogerson SJ, Chaiyaroj SC, Ng K, Reeder JC and Brown GV. Chondroitin sulfate $A$ is a cell surface receptor for Plasmodium falciparum-infected erythrocytes. J Exp Med 1995;182: 15-20.

20. Fried M and Duffy PE. Adherence of Plasmodium falciparum to chondroitin sulfate $A$ in the human placenta. Science 1996;272:1502-1504.

21. Buffet PA . Plasmodium falciparum domain mediating adhesion to chondroitin sulfate A: a receptor for human placental infection. Proc Natl Acad Sci USA 1999;96: 12743-12748.

22. Reeder JC, Cowman AF, Davern KM, et al. The adhesion of Plasmodium falciparum-infected erythrocytes to chondroitin sulfate $A$ is mediated by P. falciparum erythrocyte membrane protein 1. Proc Natl Acad Sci USA 1999;96: 5198-5202.

23. Beeson JG, Chai W, Rogerson SJ, Lawson AM and Brown GV. Inhibition of binding of malariainfected erythrocytes by a tetradecasaccharide fraction from chondroitin sulfate A. Infect Immun 1998;66:3397-3402.

24. Beeson JG, Rogerson SJ, Cooke BM, Reeder et al. Adhesion of Plasmodium falciparum-infected erythrocytes to hyaluronic acid in placental malaria.Nat Med 2000;6:86-90. 
25. Barragan A, Fernandez V, Chen Q, von Euler A, Wahlgren M and Spillmann D. The duffy-binding-like domain 1 of Plasmodium falciparum erythrocyte membrane protein 1 (PfEMP-1) is a heparan sulfate ligand that requires 12 mers for binding. Blood 2000b;95: 3594-3599.

26. Vogt AM, Barragan A, Chen Q, Kironde F, Spillmann D and Wahlgren M. Heparan sulfate on endothelial cells mediates the binding of Plasmodium falciparum-infected erythrocytes via the DBL1alpha domain of PfEMP-1. Blood 2003;101: 2405-2411.

27. Treutiger CJ, Heddini A, Fernandez V, MullerWA and Wahlgren M. PECAM-1/CD31, an endothelial receptor for binding Plasmodium falciparum-infected erythrocytes. Nat Med 1997;3: 1405-1408.

28. Kikuchi M, Looareesuwan S, Ubalee R, et al. Association of adhesion molecule PECAM-1/CD31 polymorphism with susceptibility to cerebral malaria in Thais. Parasitol Int 2001;50: 235-239.

29. Siano JP, Grady KK, Millet P and Wick TM. Short report: Plasmodium falciparum: cytoadherence to alpha (v) beta3 on human microvascular endothelial cells. Am J Trop Med Hyg 1998;59: 77-79.

30. Hasler T, Handunnetti SM, Aguiar JC, van et al. In vitro rosetting, cytoadherence, and microagglutination properties of Plasmodium falciparum-infected erythrocytes from Gambian and Tanzanian patients. Blood 1990;76:1845-1852.

31. Newbold C, Craig A, Kyes S, et al. 1999. Cytoadherence, patogenesis and the infected red cell surface in Plasmodium falciparum. Int J Parasitol 29: 927-937.

32. Nogueira PA, Wunderlich G, Tada MS, et al. Plasmodium falciparum: analysis of transcribed var gene sequences in natural isolates from the Brazilian Amazon region. Exp Parasitol 2002;101:111-120.

33. Marsh K, Marsh VM, Brown J, Whittle HC and Greenwood BM.. Plasmodium falciparum: the behavior of clinical isolates in an in vitro model of infected red blood cell sequestration. Exp Parasitol 1988;65:202-208.

34. Ho M, Singh B, Looareesuwan S, Davis TM, Bunnag D and White NJ. Clinical correlates of in vitro Plasmodium falciparum cytoadherence. Infect Immun 1991;59: 873-878.

35. Holt DC, Gardiner DL, Thomas EA, et al. The cytoadherence linked asexual gene family of Plasmodium falciparum: are there roles other than cytoadherence? Int J Parasitol 1999;29:939-944.

36. Gardiner DL, Holt DC, Thomas EA, Kemp DJ and Trenholme KR. Inhibition of Plasmodium falciparum clag9 gene function by antisense RNA. Mol Biochem Parasitol 2000;110:33-41.

37. Carcy $B$, Bonnefoy $S$, Guillotte $M$, et al. A large multigene family expressed during the erythrocytic schizogony of Plasmodium falciparum. Mol Biochem Parasitol 1994;68:221-233.

38. Bonnefoy S, Bischoff E, Guillotte M and Mercereau- Puijalon O. Evidence for distinct prototype sequences within the Plasmodium falciparum Pf60 multigene family. Mol Biochem Parasitol 1997:87:1-11.

39. Mattei D and Scherf A. The Pf332 gene of Plasmodium falciparum codes for a giant protein that is translocated from the parasite to the membrane of infected erythrocytes. Gene 1992;110:71-79.

40. Iqbal J, Perlmann P and Berzins K. Plasmodium falciparum: analysis of the cytoadherence inhibition of the human monoclonal antibody 33G2 and of antibodies reactive with antigen Pf332. Exp Parasitol 1993;77: 79-87.

41. Ahlborg N, lqbal J, Hansson M, et al. Immunogens containing sequences from antigen Pf332 induce Plasmodium falciparum-reactive antibodies which inhibit parasite growth but not cytoadherence. Parasite Immunol 1995;17:341-352

42. Ockenhouse CF, Klotz FW, Tandon NN and Jamieson GA. Sequestrin, a CD36 recognition protein on Plasmodium falciparum malaria-infected erythrocytes identified by anti-idiotype antibodies. Proc Natl Acad Sci USA 1991;88: 31753179.

43. Eda S, Lawler J and Sherman IW. Plasmodium falciparum-infected erythrocyte adhesion to the type 3 repeat domain of thrombospondin-1 is mediated by a modified band 3 protein. Mol Biochem Parasitol 1999;100:195-205.

44. Limpaiboon T, Taylor DW, Jones G, Geysen HM and Saul A.. Characterization of a Plasmodium falciparum epitope recognized by a monoclonal antibody with broad isolate and species specificity. Southeast Asian J Trop Med Public Health 1990;21: 388-396.

45. Blythe JE, Surentheran T and Preiser PR. STEVOR-a multifunctional protein? Mol Biochem Parasitol . 2004;134: 1115.

46. Cheng Q, Cloonan N, Fischer K, et al. Stevor and rif are Plasmodium falciparum multicopy gene families which potentially encode variant antigens. Mol Biochem Parasitol 1998.;97: 161-176.

47. Kaviratne M, Khan SM, Jarra W and Preiser PR. Small variant STEVOR antigen is uniquely located within Maurer's clefts in Plasmodium falciparum- infected red blood cells. Eukaryot Cell 2002;1:926-935.

48. Huji, 2004. http://www.sites.huil.ac.il/malaria

49. Papakrivos J. \& Wellems TE. Designer transport of malaria proteins in erythrocytes. Blood, Vol. 2005;105(10):37573758.

50. Voigt S, Hanspal M, LeRoy PJ, et al. The cytoadherence ligand Plasmodium falciparum erythrocyte membrane protein 1 (PfEMP-1) binds to the P. falciparum knob-associated histidine-rich protein (KAHRP) by electrostatic interactions. Mol Biochem Parasitol. 2000;110:423-428.

51. Fitri L. E. Analisis Patogenesis Malaria dengan Komplikasi. Tinjauan Molekuler Terhadap Peran Molekul Adhesi Eritrosit Terinfeksi Plasmodium falciparum Isolat Malang dan keterlibatan Senyawa Oksigen Reaktif. Disertasi PPS Universitas Brawijaya, 2004. Malang 
52. Clark I. A., L. M. Aleva., A. C. Mills., W. B. Cowden. Pathogenesis of Malaria and Clinically Similar Condition. Clinical Microbiology Reviews, 2004; 509-539

53. Ariey F, Hommel D, Le Scanf $C$, et al. Association of severe malaria with a specific Plasmodium falciparum genotype in French Guiana. J Infect Dis . 2001; 184: 237-241.

54. Kirchgatter $\mathrm{K}$ and Del-Portillo HA Association of severe noncerebral Plasmodium falciparum malaria in Brazil with expressed PfEMP-1 DBL1 alpha sequences lacking cysteine residues. Mol Med 2002; 8:16-23.

55. Jensen AT Plasmodium falciparum associated with severe childhood malaria preferentially expresses PfEMP-1 encoded by group A var genes. J Exp Med 2004;199:1179-1190.

56. Duffy MF, Brown GV, Basuki W, et al. Transcription of multiple var genes by individual, trophozoite-stage Plasmodium falciparum cells expressing a chondroitin sulfate A binding phenotype. Mol Microbiol 2002;43: 1285-1293. 